\title{
ЮРИДИЧНА ОСОБА ЯК СУБ'ЄКТ АДМІНІСТРАТИВНОГО ПРАВА: ПРОБЛЕМИ ТЕОРІї ТА ПРАКТИКИ
}

Танчик О. М.

\begin{abstract}
У науковій статті висвітлено етапи розвитку та становлення теорії юридичної особи, проаналізовано визначення поняття й ознак юридичної особи в сучасній правовій доктрині. Обгрунтовується необхідність проведення переосмислення статусу юридичної особи як суб'єкта права з погляду різних галузей правового регулювання з урахуванням практики наднаціональних правозастосовних органів і особливо адміністративно-правових методів впливу, що містять ознаки державної репресії. Зроблені висновки щодо необхідності удосконалення правового регулювання інституту адміністративної відповідальності юридичної особи.

Ключові слова: юридична особа, адміністративне правопорушення, адміністративна відповідальність, санкціі, адміністративні санкції.
\end{abstract}

В научной статье освещены этапы развития и становления теории юридического лица, проанализированы определения понятия и признаков юридического лица в современной правовой доктрине. Обосновывается необходимость проведения переосмысления статуса юридического лица как субъекта права с точки зрения различных отраслей правового регулирования с учётом практики наднациональных правоприменительных органов и особенно административно-правовых методов воздействия, которые содержат признаки государственной репрессии. Сделаны выводы относительно необходимости усовершенствования правового регулирования института административной ответственности юридических лиц.

Ключевые слова: юридическое лицо, административное правонарушение, административная ответственность, санкции, административные санкции.

The article is devoted to the coverage of one of the topical theoretical and methodological problems of administrative law in relation to the theory of a legal entity, the definition of it as a complex subject of law from the point of view of different branches of law, and not just civil. The stages of formation and development of the theory of legal entity from Roman times to the present are analyzed. The normative definition of the status and characteristics of a legal entity in the current legislation of Ukraine is given. The insufficiency of the further development of the theory of the legal entity only as a civil legal category is argued, as well as it is pointed out the necessity of improving the modern legal doctrine regarding the theory of the legal entity as a complex subject of law from the point of view of different branches of legislation, which should ensure a number of positions and trends in practice supranational law enforcement agencies. The article focuses on the problems in applying to public relations with the participation of legal entities administrative and legal methods of legal regulation, which in their essence should be equated to criminal law regulation with its principles and methods. The article also presents some of the problematic issues both in the current legislation of Ukraine and in domestic law enforcement practice regarding the category of moral harm of a legal entity, its compensation, as well as determining the guilt of a legal entity as one of the obligatory elements of the administrative offense. The article also contains conclusions on the need to take into account the status and features of a legal entity as a subject of legal regulation, which is primarily related to the practical impossibility of only a formal equation of a legal entity with an individual. At the same time, consideration of the interests of a legal entity as a collective formation created by a collective of people should, as far as possible, be secured from the point of view of observance of the basic human rights protection provided by international law enforcement institutions, the conclusions of which must be duly taken into account law in enforcement practice in Ukraine.

Key words: legal entity, administrative offense, administrative liability, sanctions, administrative sanctions.

Постановка проблеми та їі актуальність. Питання правової сутності юридичної особи як суб'єкта права виникло ще в часи зародження основ римського права, а саме відтоді, коли юридичні особи набули статусу учасника суспільних відносин як колективні інституції, держава, корпорація тощо. Особливу актуальність визначення правовосуб'єктності юридичної особи набуває в умовах запровадження сучасних принципів та умов державного управління, коли корпорації дедалі більше виступають не лише як один із засобів перерозподілу майнових благ у суспільстві, а насамперед як носії колективної волі його учасників, акціонерів, трудового колективу, держави тощо. Врахування i теоретичне переосмислення специфіки створення, існування, діяльності та вираження волі таких колективних утворень $\epsilon$ саме тією передумовою, яка повинна забезпечити здійснення ефективного й оптимального державного управління в різних сферах суспільного життя за участі таких суб'єктів. Особливо це стосується форм і методів правового регулювання, які можуть бути кваліфіковані як одна із форм державного примусу, зокрема вжиття заходів адміністративної відповідальності - адміністративних санкцій.

Аналіз останніх досліджень і публікацій. Проблему визначення сутності юридичної особи розглядали такі вчені, як: Ю.Ю. Акіменко, С.І. Аскназій, В.В. Бородін, С.Н. Братусь, А.В. Вєнєдіктов, Д.М. Гєнкін, І.П. Грєшніков, В.П. Грібанов, С.Г. Келіна, О.А. Красавчиков, В.С. Нерсесянц, А.С. Нікіфоров, І.А. Покровський, Н.О. Саніахметова, Н.С. Суворов, Ю.К. Толстой, Є.О. Харітонов, В.М. Хвостов, Є.Б. Хохлов, Б.Б. Черепахін та ін. Стосовно вивчення питань адміністративної відповідальності юридичних осіб, то слід навести таких вчених-адміністративістів, як В.Б. Авер'янов, А.П. Алехин, І.П. Голосніченко, Д.М. Лук'янець, Ю.П. Битяк, С.Т. Гончарук, Е.Ф. Демський, Є.В. Додін, В.К. Колпаков, Т.О. Коломоєць, А.А. Кармолицький, Ю.М. Козлов, А.Т. Комзюк, Л.В. Коваль, А.Н. Крамник, Н.Р. Нижник, О.І. Остапенко, Л.Л. Попов, С.Г. Стеценко, Н.Г. Саліщева, В.Д. Сорокин, А.П. Шергин та ін. 
Проте питання зазначеної проблематики потребують подальшого переосмислення та дослідження.

Метою цієї статті $€$ розкриття сутності юридичної особи як суб'єкта адміністративно-правового регулювання та формування пропозицій щодо вдосконалення правового регулювання питань адміністративної відповідальності юридичних осіб.

Виклад основного матеріалу. Сучасні принципи й умови державного управління та його правового регулювання потребують новітнього наукового дослідження і переосмислення. Особливо це стосується адміністративного регулювання правовідносин за участю юридичних осіб, їх правосуб'єктності. Зазначена проблематика стає дедалі більш актуальною із прийняттям нових нормативних актів, зокрема Кодексу адміністративного судочинства України, низки антикорупційних законів, а також нормативного визначення правозастосовної

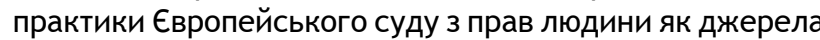
права таїі імплементаціїдоукраїнськоїправовоїсистеми.

Під впливом наднаціональних правозастосовних органів, зокрема Європейського суду з прав людини, світова правозастосовна практика вже кілька десятиліть виходить із того, що будь-яка форма державної репресії незалежно від свого найменування підпадає під поняття кримінально-правової сфери (англ. penal matter, фр. matiure pŭnale) або, що те саме, кримінального права в широкому розумінні. Будь-яка держава може технічно по-різному систематизувати репресивні норми, виходячи з власних правових традицій. Більш того, держава на цілком раціональних підставах має право також диференціювати свої репресивні норми як із матеріально-правового, так із процесуального погляду, передбачаючи у разі вчинення злочинів, адміністративних правопорушень, фінансових правопорушень, екологічних правопорушень і т. п. різні санкції, правові наслідки, різні процесуальні механізми притягнення до відповідальності та ін. [1, с. 7-8].

В Україні питання впровадження репресивних норм щодо юридичних осіб вирішено у різних галузях законодавства та передбачає відповідальність юридичних осіб у кримінальній, цивільно-правовій, податковій, екологічній, антимонопольній та інших сферах.

Незважаючи на те, що поняття юридичної особи активно використовується майже всіма галузями права, традиційно воно формувалося в рамках цивільно-правової доктрини, в контексті регулювання майнового обігу і не достатньо піддавалося комплексній теоретичній переробці з погляду різних галузей правового регулювання.

Саме від усвідомлення й осмислення правової природи юридичної особи, яка закріплена в Цивільному кодексі України, створювалася відповідно для цілей цивільно-правового обороту та не завжди враховує міжгалузеве значення поняття юридичної особи, залежить можливість подальшого розвитку і вдосконалення всіх аспектів правового регулювання повного спектру суспільних відносин за участю юридичної особи.

Проблему визначення сутності юридичної особи розглядали значна кількість вчених, проте більшість праць із цієї теми зазвичай мають цивільно-правове спрямування, водночас лише незначна кількість науковців опрацьовують теорії сутності юридичної особи саме з позиції визначення ії як суб'єкта правового регулювання у різних галузях права, в т. ч. адміністративного.
Виникнення юридично особи як суб'єкта права, що має правоздатність, яка відокремлена від фізичних осіб, що входять до їі складу, відома праву ще з римських часів і використовується в усіх правових системах світу [2, с. 25].

Конструкція юридичної особи як суб'єкта права формувалася протягом тривалого часу і під впливом різних обставин та історичних умов. Значна кількість дослідників і науковців намагалися сформувати та пояснити, що певне суспільне утворення має розглядатися і діяти як реальна людина, як особистість.

У юридичній науці наявна велика кількість теорій, які намагаються розкрити природу юридичної особи, виявити ії «субстрат», визначити сутність поняття юридичної особи та співвідношення цього поняття з поняттям суб'єкта права. Різноманітність методологічних підходів окремих авторів у вирішенні загального питання про суб'єКт права значною мірою зумовлює і різноманіття теорій юридичної особи, створення яких можна пояснити потребами практики, історичними умовами існування і діяльності тих чи інших суспільних утворень, економічними умовами конкретного суспільства. Лише аналіз таких теоретичних розробок дасть змогу проникнути у суть механізму поведінки, зокрема і протиправної, юридичної особи як підстави ії юридичної відповідальності, у т. ч. й адміністративної.

Теорії юридичної особи можна розділити на дві великі групи: концепції, що заперечують наявність певного реального суб'єкта із властивостями юридичної особи; концепції, що визнають наявність носія таких властивостей.

Одна з перших теорій юридичної особи, яка належить до першої групи і претендує на пояснення іiі природи, $\epsilon$ теорія фікції (котру нерідко ще називають «теорією уособлення»). Вона виникла у період середньовіччя та розвинулася у працях Ф.К. Савіньї, Б. Віндшейда, М. Резлера, Г.Ф. Пухти, Г. Рота, Е.Р. Бірлінга та інших учених [1, с. 16].

Н.В. Козлова у наведеній теорії виокремлює чотири напрями: 1) Ф.К. Савіньї, Г.Ф. Пухта та ін., вважають, що держава з допомогою фікції створює штучний суб'єкт права; 2) Г. Прейфер, К. Арндс, Г. Рот та ін., дотримуючись іншого напряму, зазначали, що закон не створює, а ігнорує існування штучного суб'єкта права, який відіграє роль особи; 3) третій напрям відображений у теорії персоніфікації, яка була розроблена у кінці XIX - на початку XX ст. Г.Ф. Шершеневичем, А.М. Гуляєвим, Е.Н. Трубєцким, І.М. Тюмрювовим. На їхню думку, юридична особа $є$ тим, що, не будучи фізичною особою, визнається суб'єктом права; 4) В.Б. Єльшевич дотримувався позиції, що юридична особа $є$ прийомом юридичної техніки [3, с. 109].

Суть теорії фікції полягала в тому, що, з одного боку, для досягнення мети, яка не може бути здійснена зусиллями окремих індивідів, видається доцільним створення корпорацій, котрі наділяються майновими та іншими правами, але, з іншого - відсутній реальний суб'єкт цих прав. Оскільки безсуб'єктних прав не існує і вони завжди мають належати комусь, виникає необхідність у створенні фікції.

Вказана теорія отримала значну підтримку серед науковців. Так, розглядаючи позиції зарубіжних дослідників, Г.Ф. Шершеневич писав, що у деяких ситуаціях виникає необхідність виокремити майно, яке використо- 
вуватиметься для досягнення загальної мети. Вихід може бути знайдено, якщо на місце дійсних фізичних осіб поставити уявну особу, фіктивного суб'єкта і зробити його учасником усіх відносин [4, с. 117-118].

Представники теорії фікції розмірковували про характер відповідальності юридичних осіб. Одні, враховуючи, що воля органу приписується фіктивній особі, вважали наявність вини керівників необхідною умовою відповідальності юридичної особи за помилки i правопорушення, вчинені iї органами. Інші, залишаючись прихильниками фікції, визнали, що було б несправедливо не притягати юридичну особу до відповідальності, оскільки вона користується вигодами від їх діяльності [5, с. 77].

Оскільки фікція має зміст лише у рамках нормативної системи як один із засобів, який застосовується законодавцем, то у процесі свого становлення та розвитку в теорії фікції закономірно розпочали проявлятися іï недоліки. Результатом прояву таких недоліків став процес модернізації й удосконалення деяких аспектів зазначеної теорії, почали з'являтися різновиди теорії фікції, серед яких можна навести такі: теорію цільового майна; посадового і товариського майна; колективної власності; позитивістські й нормативістські та інші подібного типу теорії юридичної особи.

Так, теорія цільового майна, яку висунув німецький юрист А. Брінц, передбачала, що майно і пов'язані з ним права й обов'язки можуть належати не певному суб'єкту, а визначеній меті, для якої воно передбачено. Тому юридична особа розглядається як майно, призначення якого - слугувати визначеній меті, т. зв. цільове майно. Прихильники цієї теорії дійшли висновку, що у праві трапляються ситуації, коли суб'єкта у дійсності немає. Зокрема, можливість наявності суб'єктивних прав без суб'єкта обґрунтовували німецькі юристи Б. Віндшейд і К. Кеппен. Також значний вклад у розвиток цієї теорії зробили Е. Демеліус, Г. Діцель, А. Брунс та ін. [3, с. 110].

Іншим варіантом розвитку теорії фікції стала теорія інтересу, запропонована Р. Ієрінгом. Він вражав, що права й обов'язки юридичної особи в дійсності належать тим реальним фізичним особам, які фактично використовують майно й отримують від нього вигоди («дестинаторам»). Їх загальний інтерес уособлює юридичну особу. На його думку, вона $€$ певним єдиним центром для прав «дестинаторів», штучно створеним за допомогою юридичної техніки для спрощення ситуації як особлива форма володіння майном багатьма фізичними особами для певних загальних цілей. Таким способом поєднувалися тези про фіктивність самої юридичної особи із визнанням реальності груп людей, що стоять за нею [6, с. 246]. Зазначену теорію підтримували та розвивали Ю.С. Гамбаров і Н.М. Коркунов [7].

Незважаючи на різноманітність цих теорій, усі вони по суті заперечували наявність юридичної особи як самостійного суб'єкта права, визначаючи їі як деяку конструкцію, створену правом, - правову фікцію, за якою стоїть адміністрація, директор, держава чи колектив.

Результатом критичного аналізу різновидів теорії фікції виявилася поява ряду теорій, які розглядали юридичну особу як реальний суб'єкт права. Вагомий внесок у розвиток цих теорій зробили К. Безелер, І.К. Блюнчлі, І.Е. Кунце, А. Лассон, О. Гірке, Г. Дєрнбург, Е. Цітєльман, П. Мішу, К. Сальковський, Р. Салейль та ін. Хоча погляди цих дослідників і мали деякі розбіжності, все ж вони збігалися у головному - в запереченні твердження, що суб'єктом права може бути лише людина [1, с. 23].

Е.К. Блюнчлі розглядав юридичну особу (головним чином державу) як живу істоту, котра володіє (як і людина) тілом і душею; таку ж позицію підтримував І.Е. Кунце. К. Сальковський вважав, що в корпорації суб'єктом є сукупність усіх їі членів у певний момент; організована єдність дійсних осіб $є$ щось реальне, а не фіктивне. А. Лассон вбачав реальність юридичної особи у кожній загальнокорисній меті. Правова особистість, на його думку, створюється тим, що люди надають їй свої фізичні й інтелектуальні можливості [8, с. 68-70].

Однією з теорій, що розглядали юридичну особу як реальний суб'єкт права, була теорія соціальних організмів, котра також отримала назву органічної теорії, автором якої $є$ німецький правознавець Отто Гірке (деякі правознавці вважають, що автором органічної теорії був Карл Безелер, а О. Гірке лише розвинув відповідні положення, але ця думка не поширена) [9, с. 107-108].

Автори цієї теорії були активними опонентами доктрини фікції та на противагу її прихильникам стверджували, що юридична особа виникає поряд із людиною шляхом природного правотворення. Ця особа реальна та має власну волю. Відповідно до цієї теорії юридична особа $\epsilon$ настільки ж реальною, як і особа фізична, утворюючи цілісну органічну єдність, яку без вагань можна назвати своєрідним суспільним організмом, що має такі самі своєрідні суспільні органи, аналогічні тим, що $є$ у людини - корпус, голову, кінцівки і навіть душу. Така особа $є$ правоздатною, аналогічно індивіду і в публічних, і в приватних відносинах. Крім того, вона дієздатна та не потребує представництва з боку інших осіб, бо має свою волю та сама діє через свої органи, створені з окремих людей. Це не представництво, оскільки тут немає заміщення однієї особи іншою, але «представлення» цілого через частину [1, с. 24].

Юридична особа, на думку О. Гірке, як і індивід, володіє органами, але органами не фізичними, а юридичними. Юридична особа може бути винною у вчиненні заборонених дій, може бути добросовісною чи недобросовісною, може помилятися, присягати, вона $\epsilon$ живим соціальним організмом [10, с. 94].

Він наполягав на тому, що індивідуальна організація повинна бути визнана правом як реальна юридична особа, така ж реальна, як і окрема людська особистість. Водночас корпорацію можна назвати організмом лише за аналогією з людиною, оскільки юридична особистість союзу не існує без визнання ії такою об'єктивним правом. Корпоративна особистість - це визнана державою здатність людського союзу як єдиного цілого бути суб'єктом прав і обов'язків. Ні людина, ні союз не створені об'єктивним правом, але вони наявні як суб'єкти права, якщо визнані як такі об'єктивним правом. Відповідно, як будь-який суб'єкт права, юридична особа володіє правоздатністю і дієздатністю, може вчиняти делікти і відповідати за них. Особливість юридичної особи полягає у тому, що вона діє через свої органи [3, с. 137].

До О. Гірке були близькими за своїми поглядами радянські вчені кінця XIX - поч. XX ст. В.М. Хвостов та І.А. Покровський. Так, В.М. Хвостов зазначав, що суб'єктом права можуть бути лише істоти, котрі мають волю. Але такими особами $\epsilon$ не тільки фізичні особи, a й особливі соціальні організації, які мають свою 
власну волю. Ці окремі організації наявні так само реально, як і фізичні особи [9, с. 107-108].

За допомогою цієї теорії юридичні особи в окремих державах почали визнаватися деліктоздатними. Безумовно, ця теорія дозволила дати відповідь на питання щодо можливості притягнення організацій, що володіють властивостями юридичної особи, до відповідальності за вчинення протиправних дій.

Органічна теорія стала передумовою створення іншої групи теорій юридичних осіб, т. зв. реалістичних теорій, прихильники яких розглядали юридичну особу як колективне утворення, що $є$ органічним об'єднанням людей в одне ціле, але одночасно має свою власну, відокремлену від волі учасників волю і діє з метою забезпечення спільних інтересів своїх членів.

Учені - прихильники реалістичних теорій розглядали юридичну особу як соціальну реальність, котра володіє самостійною волею і самостійним інтересом, які відрізняються від волі та інтересів тих осіб, що їі становлять. Юридична особа визнається здатною вчиняти суспільно значимі дії, як правомірні, так і протиправні (делікти). Якщо орган такої особи у рамках своїх повноважень вчинив протиправні дії, то ці дії можна вважати діями і волею самої юридичної особи, за що остання повинна самостійно відповідати.

Згідно з теорією соціальної реальності основна ідея інституту юридичної особи - створення суб'єкта права, який існує і діє незалежно від зміни ії людського складу, а тому ніхто не стоїть за юридичною особою, подібно до того, як ніхто не стоїть за громадянином як суб'єктом прав і обов'язків. Майно і права юридичної особи належать ій самій і не належать людям, які складають їі людський субстрат [11, с. 44-45]. Таким чином, прихильники цієї теорії обмежилися лише характеристикою юридичної особи як соціальної реальності, залишивши поза сферою дослідження людей, котрі входять до їі складу.

Реалістичну теорію О. Гірке на початку XX ст. розвинули П. Мішу та Р. Салейль. На їхню думку, юридична особа - це суспільне утворення, яке має свою волю, діє з метою забезпечення деяких загальних інтересів, пов'язуючи в одне ціле визначену групу людей. Вони вважали, що юридична особа як реальність володіє волею та інтересом, відмінними від волі та інтересів індивідів, які її складають [5, с. 105].

Однією з особливостей як органічної теорії, так і теорії соціальної слід відзначити те, що відповідно до цих теорій і на відміну теорії фікції Ф.К. Савіньї юридична особа як колективна особистість не створюється, а лише визнається правом. Тобто відповідно до зазначених теорій необхідно не створювати, а лише враховувати утворення, котрі набувають статус юридичної особи.

Значення теорії юридичної особи як реального суб'єкта для подальшого розвитку науки про вказаний суб'єкт права важко переоцінити. По-перше, наука визнала реальну наявність у суспільному житті юридичної особи як суб'єкта права; по-друге, наука вказала на вирішальне значення об'єктивного права для виникнення юридичної особи; по-третє, знайдено субстрат, який виражає волю юридичної особи, - його органи, наділені відповідними повноваженнями; по-четверте, зазначено, що всі дії органів юридичної особи (у т. ч. й протиправні) $є$ діями самої юридичної особи, а отже, вона не лише може, але й повинна підлягати за ці дії від- повідальності. Фактично на такій методологічній основі пізніше, уже в радянській цивілістиці, значну популярність здобули такі теорії щодо сутності юридичної особи: «теорія колективу», яку наприкінці 20-х рр. XX ст. підтримував А.В. Вєнєдіктов; «теорія держави» (теорія власника), автором якої був С.І. Аскназій; «теорія директора», що найбільш повно досліджена у роботах Ю.К. Толстого та ін. Спільною для всіх перелічених концепцій $\epsilon$ ідея про наявність людського субстрату (фізичної особи чи колективу) у юридичній особі.

Сучасна доктрина юридичної особистості корпорацій загалом базується або на теорії фікцій, або на органічній (реалістичній), або на позитивістських теоріях юридичної особи, практично не вносячи нічого принципово нового в жодну з них. Водночас, як це не парадоксально, наявна і нині множинність теорій юридичної особи не завдає негативного впливу на практику його функціонування. Першочергова мета, яка стояла перед дослідниками феномену юридичної особи, - обґрунтування розмежування майна корпорації та учасників цієї корпорації, а також третіх осіб. Саме спільність вказаної мети, незважаючи на різнобій думок, об'єднує теорії юридичної особи та дозволяє всім їм чудово обслуговувати потреби сучасного капіталістичного обігу. Юридична особа постає суб'єктом як публічного, так і приватного права, що вступає в цивільні, адміністративні, кримінальні та трудові відносини від свого власного імені та відповідає в рамках цих відносин власним майном [12].

У ст. 80 Цивільного кодексу України, яка називається «Поняття юридичної особи», під юридичною особою розуміється організація, котра створена та зареєстрована у встановленому законом порядку, наділена цивільною правоздатністю та дієздатністю, може бути позивачем і відповідачем у суді [13].

Тобто законодавець не надає визначення поняття юридичної особи, але вказує на деякі характерні ознаки цього поняття, тому маємо лише вказівки на такі ознаки юридичної особи: 1) це «організація», тобто певним чином організаційно і структурно оформлене соціальне утворення; 2) вона має бути створена і зареєстрована у встановленому законом порядку; 3) вона має цивільну правоздатність і дієздатність (правосуб'єктність), тобто здатна набувати і реалізовувати цивільні права й обов'язки від свого імені; 4) вона може бути позивачем і відповідачем у суді.

Однак серед цих властивостей не вистачає деяких традиційних ознак юридичної особи: наявності відокремленого майна, самостійної відповідальності за зобов' язаннями.

У теорії цивільного права на підставі систематичного тлумачення норм Цивільного кодексу України зазвичай виділяють такі чотири кваліфікуючі ознаки, притаманні юридичній особі: а) організаційну єдність (організація відповідно до цього критерію повинна складати єдине ціле); б) майнову відокремленість (означає наявність у організації майна на праві власності, або на праві господарського відання, або на праві оперативного управління); в) самостійну майнову відповідальність (засновники, учасники, а також інші особи за загальним правилом не відповідають за борги юридичної особи); г) участь у цивільному обороті від свого імені (організація має можливість від свого ім'я набувати та здійснювати права, нести обов'язки, бути позивачем і відповідачем у суді) [14, с. 114-116]. 
Водночас юридична особа в контексті застосування прецедентної практики Європейського суду з прав людини (далі - ЄСПЛ) також здійснює суттєвий вплив на зміну уявлень щодо її правосуб'єктності в широкому сенсі щодо комплексу правовідносин, і не лише цивільно-правових. Правозастосовна практика ЄСПЛ $є$ частиною української правової системи, а його рішення $\epsilon$ обов'язковими для виконання на території України, тому законодавцю необхідно враховувати висновки ЄСПЛ під час законотворчої діяльності. Неабияке значення для цього мають доктринальні правові позиції науковців щодо цих питань, які по суті слугують підґрунтям, основою для забезпечення правового регулювання суспільних відносин.

Стосовно захисту прав юридичних осіб на підставі положень Конвенції про захист прав людини та основоположних свобод 1950 р. (далі - ЄКПЛ, Конвенція), то слід зауважити, що особливість полягає в тому, що юридичні особи можуть користуватися не всіма правами, закріпленими ЄКПЛ [15]. Вони, наприклад, не можуть скаржитися на порушення права на життя, на свободу й особисту недоторканність, на повагу до приватного і сімейного життя й деякі інші. Аналіз скарг юридичних осіб до ЄСПЛ засвідчує, що юридичні особи найчастіше скаржаться на порушення таких прав, як право власності (ст. 1 Протоколу 1 до ЄКПЛ); право на справедливий і публічний розгляд справи упродовж розумного строку незалежним і безстороннім судом (ст. 6 Конвенції); право на свободу думки, совісті і релігії (ст. 9 Конвенції); право на свободу вираження поглядів (ст. 10 Конвенції); право на свободу зібрань та об'єднань (ст. 11 Конвенції); право на ефективні засоби правового захисту (ст. 13 Конвенції); право не піддаватися дискримінації (ст. 14 Конвенції) [16, с. 107-108].

У плані визначення кола суб'єктів, яким може присуджуватися компенсація за завдану моральну шкоду, принципове значення має однозначне визнання ЄСПЛ можливості застосування такого способу захисту також і в інтересах юридичних осіб. Напевно, можна говорити про потенційно необмежений за видами й організаційно-правовими формами перелік приватних юридичних осіб - зокрема, ними можуть бути і непідприємницькі (громадські, релігійні організації, політичні партії тощо), і підприємницькі товариства. Наочною ілюстрацією тому слугує рішення у справі «С.А. Комінгерсол проти Португалії», у якому Суд визнав можливість стягнення компенсації за моральну шкоду, завдану комерційному товариству. Серед складників імовірних немайнових втрат такої юридичної особи було названо непевність у плануванні необхідних рішень, порушення в управлінні підприємством і навіть («хоча й меншою мірою») страх і неприємності, що їх відчували члени органів управління товариства [17, с. 922-923].

Наслідування позиції Суду в означеному питанні відкриває широкі можливості для реалізації функцій відшкодування моральної шкоди як заходу цивільно-правової відповідальності у разі порушення прав юридичної особи неправомірними рішеннями, діями чи бездіяльністю органів або посадових осіб публічної адміністрації. В означених правових ситуаціях, на нашу думку, юридичним особам має бути гарантоване право на стягнення відповідної компенсації незалежно від конкретного втілення завданої їм немайнової шкоди, яка може виявлятися не тільки у приниженні ділової репутації, а й в інших формах негативних немайнових наслідків вчиненого правопорушення [18, с. 261].

На фоні існування такої правозастосовної практики ЄСПЛ щодо захисту прав юридичних осіб існує очевидний дисонанс між розумінням і сприйманням юридичної особи в законодавстві України та в розумінні міжнародних інституцій і наднаціональних правозастосовних органів.

3 питання відшкодування моральної шкоди юридичній особі, яка може бути виражена не лише як втрата іміджу чи ділової репутації, але і як моральні переживання чи страждання фізичних осіб - членів органів управління, власників тощо, випливає інше дискусійне питання вини юридичної особи, а точніше ії відсутності, коли законодавець передбачає можливість застосування адміністративних санкцій до юридичних осіб за відсутності вини як елементу складу правопорушення у формі умислу чи необережності з боку суб'єкта відповідальності - юридичної особи.

До таких прикладів відповідальності можна віднести: нарахування пені за порушення граничних строків розрахунків за операціями з експорту й імпорту товарів (ч. 5 ст. 13 Закону України «Про валюту та валютні операції») [19]; за недотримання нормативу робочих місць для працевлаштування осіб з інвалідністю (ст. 20 Закону України «Про основи соціальної захищеності осіб з інвалідністю в Україні») [20]; вчинення податкових правопорушень (ст. 109 Податкового кодексу України) [21] та ін.

Притягнення без наявності вини до адміністративної відповідальності фізичних осіб $є$ майже неможливим, водночас щодо юридичних осіб такі обставини та факти часто зустрічаються. I це все на фоні майже рівнозначного підходу ЄСПЧ до захисту прав юридичних і фізичних осіб у світлі Конвенції та протоколів до неї, а також віднесення будь-якої форми державної репресії під поняття кримінального права в широкому розумінні.

Слід зазначити, що в національному законодавстві України не завжди дотримується принцип рівнозначного підходу до гарантій захисту прав фізичних і юридичних осіб, чого лише вартує показове у цьому плані рішення Конституційного Суду України у справі за конституційним зверненням Національного банку України щодо офіційного тлумачення положення ч. 1 ст. 58 Конституції України (справа про зворотну дію в часі законів та інших нормативно-правових актів) від 09 лютого 1999 р. У вказаному рішенні суд оголосив, що ч. 1 ст. 58 Конституції України, яка передбачає, що Закони та інші нормативно-правові акти не мають зворотної дії в часі, крім випадків, коли вони пом'якшують або скасовують відповідальність особи, не поширюється на юридичних осіб, а поширюється тільки на людину та громадянина (фізичну особу) [22, с. 57].

Висновки. Підсумовуючи викладене, необхідно зазначити, що юридична особа в сучасному розумінні теоретиків права розглядається лише як інструмент і визначається тільки через властивості, які відрізняють його від інших інструментів, але законодавець нічого не говорить про те, для чого слугує такий інструмент, і тим більше не розглядає юридичну особу як повноцінний суб'єкт права. Водночас, розглядаючи юридичну особу як об'єкт адміністративно-правового впливу з боку держави, необхідно насамперед враховувати обставини існування і динаміки розвитку правозастосовної практики ЄСПЛ щодо захисту прав юридичних 
осіб, своєчасно і системно ліквідовувати дисонанс між розумінням і сприйманням юридичної особи у правозастосовній практиці України та наднаціональних правозастосовних органів.

Юридична особа має свої ознаки й особливості створення і діяльності, своє призначення і як колективне утворення виражає свою волю через діяльність колективу людей, а тому для забезпечення ефективності заходів правового впливу на юридичну особу необхідно враховувати специфіку самого об'єкта впливу.

У сучасному світі стає дедалі більш утрудненим і необ'єктивним ставлення до юридичної особи як до фіктивного утворення, створеного для забезпечення реалізації тих чи інших інтересів фізичних осіб, сучасна корпорація стає більше схожою на колективний організм з усіма притаманними живому організму ознаками потребами, правами й обов'язками. Від теоретичного переосмислення такого значення та місця юридичної особи в сучасному світі залежить можливість подальшого правильного й об'єктивного регулювання суспільних відносин за їх участі, забезпечення обрання таких методів адміністративного впливу, які можуть бути більш ефективними з одночасним збереженням балансу інтересів між суб'єктом і об'єктом такого регулювання.

\section{Література}

1. Грищук В.К., Пасєка О.Ф. Кримінальна відповідальність юридичних осіб: міжнародний досвід та основні теоретичні підходи : науково-практичний посібник. Київ : Юрінком Інтер, 2017. 296 с.

2. Шевченко Я.М., Малявко О.М., Салатко А.Л. та ін. Розвиток цивільного і трудового законодавства в Україні. Харків : Консум, 1999. 271 с.

3. Козлова Н.В. Понятие и сущность юридического лица. Очерк истории и теории : учебное пособие. 2003. 318 c. URL: https://lib.sale/yuridicheskih-lits-pravo/ yuridicheskie-litsa-rimskom-79713.html (дата звернення: 25.01.2020).

4. Шершеневич Г.Ф. Учебникъ русскаго гражданскаго права. Санкт-Петербургъ : Изданіе Бр. Башмаковыхъ, 1907. 556 c. URL: https://naukaprava.ru/catalog/297/699/ 18458?view=1 (дата звернення: 25.01.2020).

5. Братусь С.Н. Юридические лица в советском гражданском праве. Ученые труды: Понятие, виды, государственные юридические лица. Москва : Юрид. изд-во Министерства юстиции СССР, 1947. 364 с.

6. Суханов Е.А. Гражданское право : учебник : в 2 т. / под ред. Суханова Е.А. Москва : Волтерс Клувер, 2004-2005. 404 C.

7. Гамбаров Ю.С. Курс гражданского права. Т. 1. Общая часть. Санкт-Петербург, 1911. С. 450-452; Коркунов Н.М. Лекции по обшей теории права. Санкт-Петербург, 1914. 148 c.

8. Герваген Л.Л. Развитие учения о юридическом лице. Санкт-Петербург : Типография И.Н. Скороходова, 1888. $91 \mathrm{C}$

9. Хвостов В.М. Система римськаго права. І. Общая часть. Конспектъ лекций. Петербургъ, 1908. 204 с. URL: https://naukaprava.ru/catalog/435/823/ 5123/31488? view $=1$ (дата звернення: 25.01.2020).
10. Суворов Н.С. Об юридических лицах по римському праву / науч. ред. В.С. Ем и Н.В. Козлова; Московский государственный университет им. М.В. Ломоносова. Москва : Статут, 2000. 299 с. URL: https: / / azbyka.ru/otechnik/Nikolaj Suvorov/ ob-yuridicheskih-litsah-po-rimskomu-pravu/\#0_4 (дата звернення: 25.01.2020).

11. Черепахин Б.Б. Волеобразование и волеизъявление юридического лица. Правоведение. 1958. № 2. С. 43-50.

12. Хохлов Е.Б., Бородин В.В. Понятие юридического лица: история и современная трактовка. Государство и право. 1993. № 9. С. 153-156.

13. Цивільний кодексУкраїни : Закон від 16 січня 2003 p. № 435-IV / ВP України. URL: https://zakon.rada.gov.ua/ laws/show/435-15 (дата звернення: 25.01.2020).

14. Цивільне право України : підручник : у 2 т. / за заг. ред. В.І. Борисової, І.В. Спасибо-Фатєєвої, В.Л. Яроцького. Київ : Юрінком Інтер, 2004. Т. 1. 656 с.

15. Конвенція про захист прав людини і основоположних свобод : ратифікована Законом № 475/97-ВР від 17 липня 1997 р. / ВР України. URL: https://zakon.rada.gov.ua/ laws/show/995_004 (дата звернення: 25.01.2020).

16. Данелія О.С. Юридичні особи як суб'єкти звернення до Європейського суду з прав людини. Наукові записки Інституту законодавства Верховної Ради України. 2017. № 1. C. 107-108.

17. Де Сальвиа М. Прецеденты Европейского Суда по правам человека. Руководящие принципы судебной практики, относящиеся к Европейской конвенции о защите прав человека и основных свобод. Судебная практика с 1960 по 2002 г. Санкт-Петербург : Юридический центр Пресс, 2004. С. 922-923.

18. Примак В.Д. Відшкодування моральної шкоди у рішеннях Європейського суду з прав людини: орієнтири для вітчизняного законодавця і судової практики. Науковий вісник Ужгородського національного університету. 2013. Вип. 23. Ч. 1. Т. 1. С. 258-262.

19. Про валюту та валютні операції : Закон від 21 червня 2018 р. № 2473-VIII / ВP України. URL: https://zakon.rada.gov.ua/laws/show/2473-19 (дата звернення: 26.01.2020).

20. Про основи соціальної захищеності осіб з інвалідністю в Україні : Закон від 21 березня 1991 р. № 875-XII / BP України. URL: https://zakon.rada.gov.ua/laws/show/ 875-12 (дата звернення: 26.01.2020).

21. Податковий кодекс України : Закон від 02 грудня 2010 р. № 2755-VI / ВP України. URL: https://zakon.rada.gov.ua/laws/show/2755-17 (дата звернення: 26.01.2020).

22. Рішення Конституційного Суду України від 30 травня 2001 р. № 7-рп/2001 по справі № 1-22/2001 за конституційним зверненням відкритого акціонерного товариства «Всеукраїнський Акціонерний Банк» щодо офіційного тлумачення положень п. 22 ч. 1 ст. 92 Конституції України, ч. 1, 3 ст. 2, ч. 1 ст. 38 Кодексу України про адміністративні правопорушення (справа про відповідальність юридичних осіб). Офіційний вісник України. 2001. № 24. С. 57.

Танчик О. М., здобувач кафедри державно-правових дисчиплін юридичного факультету Харківського національного університету імені В. Н. Каразіна 